\title{
Evaluation of airfield pavement micro and macrotexture in the light of skid resistance (friction coefficient) measurements
}

\author{
Mariusz Wesołowski ${ }^{1, *}$ and Krzysztof Blacha ${ }^{1}$ \\ ${ }^{1}$ Air Force Institute of Technology, Airfield Pavement Division, 01-494 Warsaw, Poland
}

\begin{abstract}
Appropriate skid resistance properties of airfield pavements are extremely important in terms of the safety of air operations. When discussing skid resistance properties of airfield pavements, we should not limit the subject only to the friction coefficient, which determines the state of its roughness. Attention should be paid to the fact that a significant component of friction characteristics of a tyre/pavement contact surface is the pavement texture (microtexture and macrotexture). The authors of the article presented the currently applied study methods in the scope of evaluating the texture of road and airfield pavements. The paper also presents sample results of field tests, which were conducted on new airfield pavements (executed in the cement concrete and asphalt concrete technology), as well as their short analysis in relation to evaluating the skid resistance properties (friction coefficient). Particular attention was paid to the current requirements in this scope, imposed on airfield pavements and the assessment criteria of the obtained results. Moreover, the paper also presents a direction of further works conducted by the authors with a broader team, in the scope of developing the study method for the assessment of airfield pavement texture.
\end{abstract}

\section{Introduction}

Airfield pavement, in the aspect of air operation execution safety, is characterized by determining its technical condition. One of the elements of this process is assessing the roughness through measuring the friction coefficient, which is the basic parameter characterizing its skid resistance properties.

The friction coefficient is a non-dimensional ratio of the friction force between two bodies and the normal pressure force of these two bodies [1]. It is an extremely important parameter for the correct trajectory of an aircraft moving on airfield pavement. The best of the currently used braking systems will not work if an aircraft wheel does not exhibit appropriate grip to the surface. Aviation events, in which an aircraft goes outside a runway or the taxi path, because of the loss of grip, were recorded in the past and are recorded now. This is why, already at the airfield pavement engineering stage, the designers take into account the pavement skid resistance parameters obtained in the future. In for an airplane to exhibit delayed movement, the braking forces must be balanced by the friction force. When the braking forces exceed the friction forces, a wheel starts to skid along the pavement, and as a result, a pilot partially or fully loses control over the machine.

Considering the issue of friction, it can be stated that it is incorrect to assign the origin of the friction coefficient solely to the pavement, i.e., it can be concluded that the friction process includes [1]:

- airfield pavement (slope, temperature, contaminations, macrotexture, microtexture and grooving);
- tyres (tread thickness and pressure);

- contaminants (between the tyre and the pavement);

- atmosphere (precipitation, wind and temperature).

A property in a direct relation with the friction coefficient is the pavement texture (micro and macrotexture).

Microtexture also characterizes the unevenness of the pavement in a wavelength range below $0.5 \mathrm{~mm}$ (texture up to $0.5 \mathrm{~mm}$ deep) [2,3]. Microtexture is associated with the texture of individual stones, which is hard to catch with a naked eye. It is an element embedded in the pavement and a basic component in preventing skidding at low velocities. A thin layer of water on wet pavement at greater velocities, may prevent direct contact between pavement irregularities and a tyre, due to insufficient drainage of water from the tyre/pavement contact surface. It may change over a short period of time without being detected. A typical example is the accumulation of rubber sediments in the touchdown area, which will mask a microstructure, to a large extent, without the need to reduce the macrostructure [4]. Microstructure is assessed in an indirect manner, based on the PSV (Polished Stone Value) aggregate polish ability index [5]. Through determining aggregate, which is able to withstand microstructure polishing, the drainage of thin layers of water is ensured for an extended period of time. Resistance to polishing is expressed in the form of the polished stone value $(P S V)$, which is a value achieved as a result of measuring friction according to international standards. These standards define PSV minima, which enable selecting a material with good microstructure [4].

On the other hand, macrostructure characterizes the pavement irregularities over a wavelength range of

*Corresponding author: mariusz.wesolowski@itwl.pl 
0.5-50 $\mathrm{mm}$ (texture more than $0.5 \mathrm{~mm}$ deep) $[2,3]$. Most of all, it enables draining water from the tyre/pavement surface at high velocities. It is associated with the texture between individual stones. Macrostructure is mainly composed by the size of the used aggregate or through surface treatment. If pavement has good macrostructure, enabling draining water from under the tyres, then the friction will depend on the velocity to a smaller degree. Whereas, bad macrostructure causes increased decline of the friction value with increasing velocity.

Currently, pavement texture is the subject of standard tests and operational requirements, both for airfield, as well as road pavements. However, despite the fact that it is an important component of the tyre/pavement contact surface friction characteristics, the friction coefficient is decisive in the aspect of evaluating the skid resistance properties of airfield pavements.

\section{Requirements and test methods}

\subsection{Requirements for airfield pavements}

The requirements regarding texture depth, which must be satisfied by airfield pavements are included in the document issued by global aviation institutions, such as ICAO (International Civil Aviation Organization) FAA (Federal Aviation Administration) and the highest European aviation institution, namely, EASA (European Aviation Safety Agency).

Analysing ICAO [6, 7] and EASA [4] documents, the requirements in the scope of airfield pavement texture are identical, i.e., the mean texture depth for new airfield pavements should not be lower than $1.0 \mathrm{~mm}$. In the case of the FAA document [8], the requirement for new pavements is $1.14 \mathrm{~mm}$. According to [9], pavements characterized by a texture depth (macrotexture) below $1 \mathrm{~mm}$ are still able to exhibit good properties in terms of roughness, but within a short period of time might require actions aimed at improving their skid resistance properties. The basic method, which can be applied in such a situation, is grooving the pavement (Fig. 1). The basic aim of this treatment is to improve the pavement water drainage system. Natural drainage may be slowed down by the texture, but grooving can accelerate it through ensuring shorter water drainage path and increasing its speed.

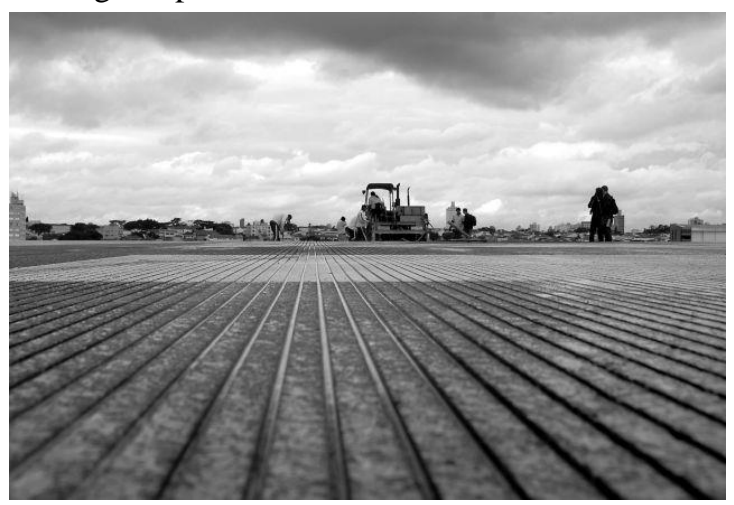

Fig. 1. An example of a grooved airfield pavement in the cement concrete technology [source: www.nasa.gov].
The mentioned documents define the requirements for new airfield pavements. However, it should also be noted that they mainly apply to runway requirements. Moreover, these documents do not stipulate the minimum values, as in the case of the friction coefficient for individual pavement sectors, i.e.: "value for new pavement", "values for pavements in operation, after exceeding which remedial actions should be taken" and „, minimum limit values”.

Given the above, a question comes to mind - what are the requirements in the scope of texture depth for pavements on other airfield functional elements (AFE)? Maybe due to lower velocities of the aircraft moving over them, it is not that important. However, looking only at the required minimum values of the friction coefficient, they are not limited to only the runway, but also apply to all AFE surfaces.

Going back to the requirement in terms of texture depth, there is a classification with macrotexture categories, from A to E (Tab. 1). The classification was developed with the use of "sand and grease" measurement techniques and published in 1971 by Engineering Sciences Data Unit (ESDU) [4, 6].

Table 1. Runway classification based on ESDU 71026 information on texture $[4,6]$.

\begin{tabular}{|c|c|}
\hline Classification & $\begin{array}{c}\text { Texture depth } \\
\text { (mm) }\end{array}$ \\
\hline A & $0.10-0.14$ \\
\hline B & $0.15-0.24$ \\
\hline C & $0.25-0.50$ \\
\hline D & $0.51-1.00$ \\
\hline E & $1.01-2.54$ \\
\hline
\end{tabular}

When using this classification, the threshold value between a microtexture and macrotexture is $0.1 \mathrm{~mm}$ of the mean texture depth (MTD).In reference to this scale, normal aircraft performance on a wet runway are based on a texture providing water drainage and friction properties in the centre of the classification, between B and $\mathrm{C}(M T D$ at a level of $0.25 \mathrm{~mm})$. It should be understood that such a texture ensures safe execution of air operations. Improving drainage through a better texture may qualify to a better class of aircraft performance. However, such classification must be conducted as per the airplane manufacturer documentation and must be stipulated by the State. Currently, the classification for runways with a grooved or porous layer is provided, after meeting the criteria in the field of engineering, construction and maintenance, acceptable by a given State. Uniformed certification standards of some States apply to a texture ensuring water drainage and friction properties in the centre of the classification between $\mathrm{D}$ and $\mathrm{E}$ (MTD at a level of $1.0 \mathrm{~mm}$ ).

ESDU scale groups runway pavements based on macrotexture from A to E, where E means pavement with 
best dynamic water drainage capabilities. Therefore, this scale reflects the dynamic water drainage characteristic. Undoubtedly, grooving improves these capabilities. Thus, created drainage capabilities are a function of the texture (A to E) and grooving. Grooving effectiveness is made up of the size of the grooves and spacing between them. Airfield exposed to large or torrential rainfall should enable that the pavements and adjacent areas had water drainage capabilities sufficient to withstand such rainfall. Otherwise, pavement use in extreme conditions should be limited. Such airports should also try to ensure maximum permissible slope and the use of aggregate, providing sufficiently good drainage properties. They should also consider providing grooved surfaces in the E class, in order to make sure that the safety level was not decreased.

\subsection{Airfield pavement evaluation methods}

Simple methods were described for testing airfield pavements, like the "sand and grease" method, described in ICAO [9] and FAA [8] documents, which is the basis for today's study methods.

Nowadays, an airfield pavement structure evaluation is performed with the volumetric method (measuring the mean texture depth $M T D$ ) acc. to PN-EN 13036-1:2010 Road and airfield surface characteristics. Test methods Part 1: Measurement of pavement surface macrotexture depth using a volumetric patch technique [10] or the profilometric method (measuring the mean profile depth MTD) acc. to PN-EN ISO 13473-1:2005 Characteristics of pavement structure with the use of surface profiles. Part 1: Determination of the mean depth profile [2].

\subsubsection{Volumetric method}

The so-called "calibrated sand method" (or the sand patch method) has been (and is still) commonly used for many years all over the world to measure the surface texture. The volumetric method has a scope of application from $0.25 \mathrm{~mm}$ to $5 \mathrm{~mm} M T D$.

The method involves spreading a specific volume of granular material (usually sand or glass beads) in a circular manner over a tested surface. Full glass beads, with at least $90 \%$ passing through a $0.25 \mathrm{~mm}$ sieve and stay on an $0.18 \mathrm{~mm}$ sieve are used today. A flat hard disk with a diameter of $65 \mathrm{~mm}$ and a thickness of about $25 \mathrm{~mm}$ is used to spread the material on the surface, covered with a layer of hard rubber on the bottom surface. A macrotexture test assembly is shown below (Fig. 2).

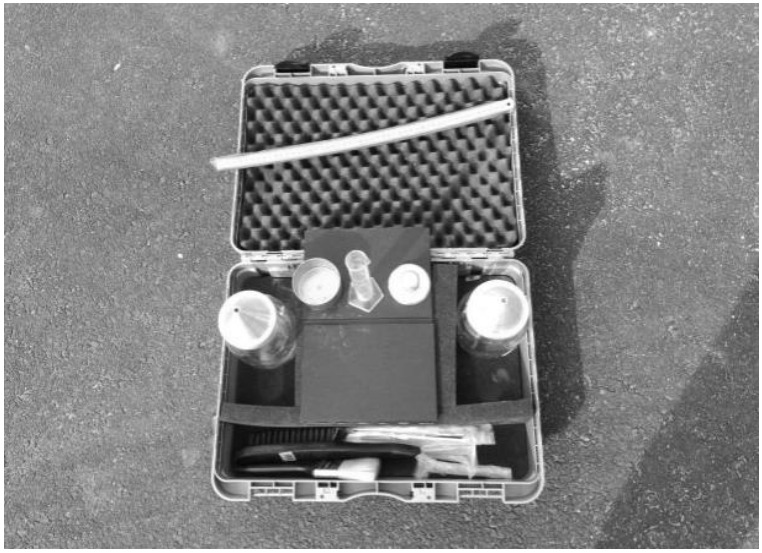

Fig. 2. Texture testing assembly [source: AFIT archives].

The measured value is an averaged diameter of the formed patch (Fig. 3).

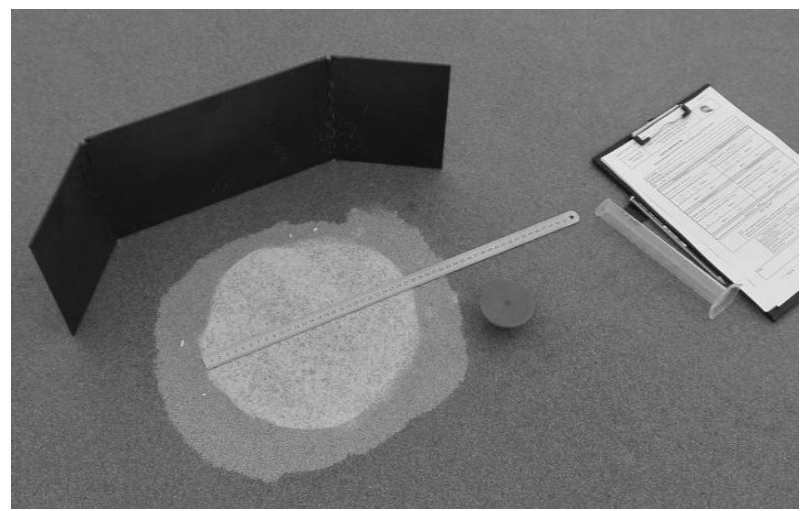

Fig. 3. View of a formed patch [source: AFIT archives].

The test result is the mean texture depth $M T D$, obtained from the formula:

$$
M T D=\frac{4 V}{\pi D^{2}}
$$

where:

$M T D$ - mean texture depth [mm]

$V \quad$ - granular material sample volume $\left[\mathrm{mm}^{3}\right]$

$D$ - diameter of the sphere covered with granular material $[\mathrm{mm}]$

The granular material sample volume is calculated from the formula:

$$
V=\frac{\pi D^{2} h}{4}
$$

where:

$V \quad$ - granular material sample volume $\left[\mathrm{mm}^{3}\right]$

$d \quad$ - internal diameter of container filled with granular material [mm]

$h$ - height of container filled with granular material [mm]

Please remember to inspect the surface to be tested, and select a dry, uniform area, which does not contain any elements such as expansion gaps. A surface should be thoroughly cleaned with soft brushes, in order to remove the residues of loose aggregate grains and other 
contaminants. Additionally, a portable wind-protector shall be placed on the tested surface.

\subsubsection{Profilometric method}

The range of application of the profilometric method is 0 $\mathrm{mm}$ to $5 \mathrm{~mm} M P D$. When using this method, the threshold value between a microtexture and mactrotexture is 0.5 $\mathrm{mm}$.

The method utilizes a measurement of the pavement surface profile through a high sampling frequency laser sensor. Measuring with this method provides us with a surface profile, which is further analysed, and the so-called mean profile depth $M P D$ is determined. Theprofile shows the pavement in two dimensions and is described by two coordinates: distance (along the pavement surface) and amplitude (perpendicular to the pavement surface).

The $M P D$ value may be transformed into estimated texture depth ETD. The transformation equation also has to be used:

$$
E T D=0,2+0,8 \times M P D
$$

Using the a/m equation should result in an ETD value as close to the $M T D$ value measured with the volumetric method. An error in the transformation equation is deemed much smaller than the spread of the volumetric method results associated with a measurement conducted by different operators.

Similar to the volumetric method, the measurements should not be performed during rain or snowfall. The pavement should be dry, cleaned and free from any contamination.

Profilometres of various types may be used for the measurements, and they include [2]:

- mobile, high speeds (may be installed on a vehicle and used at speeds of $60 \mathrm{~km} / \mathrm{h}$ and greater);

- mobile, low speeds (may be installed on a vehicle and used at speeds lower than $60 \mathrm{~km} / \mathrm{h}$ );

- stationary, without stopping traffic (road measurements);

- stationary, with stopped traffic (road measurements).

Due to the rapid pace of technological development, newer measuring units are being created (Fig. 4 and Fig. 5). Advanced scanners enable precise scanning of the surface and continuous calculation of the results during the travel of a measuring unit.

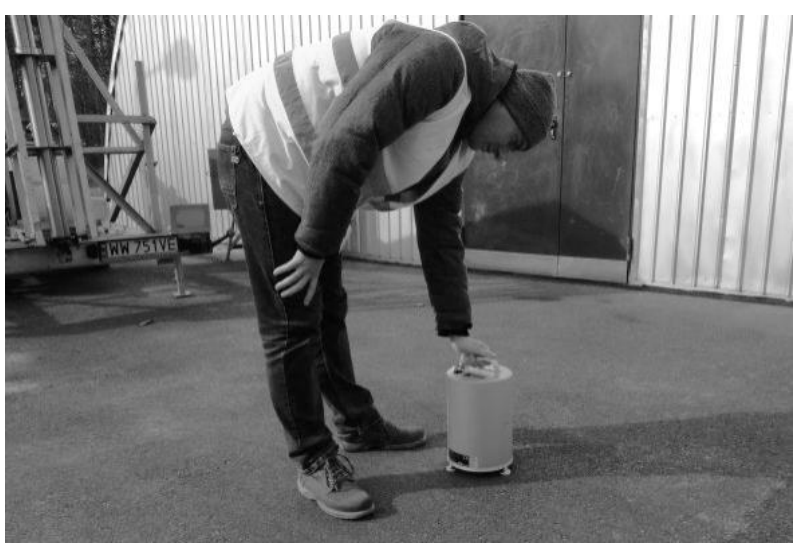

Fig. 4. ELATextur device for macrotexture measurements [source: AFIT archives].

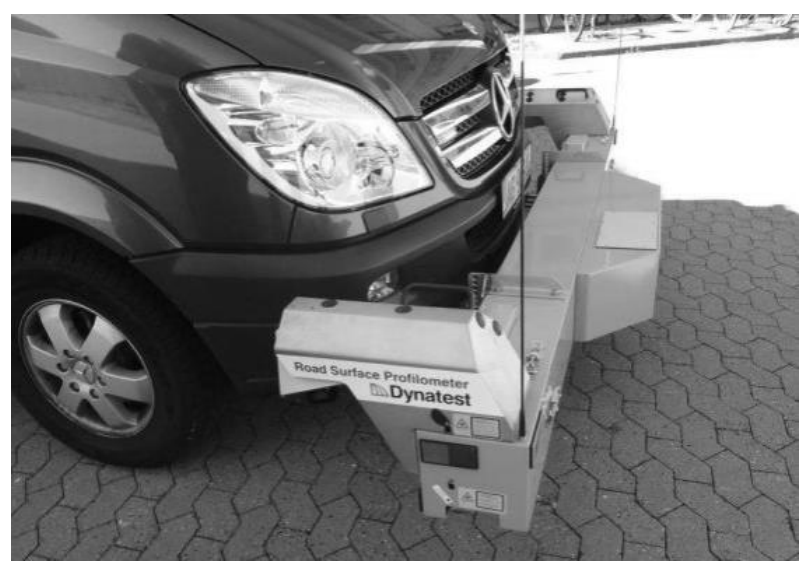

Fig. 5. RSP Profilograph [source: www.google.pl].

\subsection{Road surface evaluation methods and requirements}

The requirements in the field of road surface technical condition, including their skid resistance properties (friction coefficient, texture), are based on national documentation, i.e., for example, requirements regarding highways were defined in the regulation of the Minister of Infrastructure of 16 January 2002 on the technical and construction legislation regarding toll-ways [11].

Pursuant to the aforementioned regulation, when evaluating the skid resistance properties of highway surfaces, one needs to determine the macrotexture depth and the friction coefficient through [11]:

- measuring the pavement macrotexture depth (TD) with a method equivalent to the calibrated sand method;

- measuring the friction coefficient corresponding to a $100 \%$ skid of a test tyre, on a water-wetted surface.

The macrotexture depth $T D$ is determined according to the formula [11]:

$$
T D=2,3 \times R M S-0,2
$$

where:

$T D$ - texture depth [mm]

$R M S$ - recorded profile standard deviation 
Unfortunately, the above formula, stated in the regulation [11], does not apply to the volumetric method for macrotexture measurement and the phrase "with an equivalent method". A reliable depth for a tested section, that is the difference between the mean value and standard deviation $S$ of a set of $T D$ values over the tested section $(T D-S)$ is compared with the threshold values given in the table of macrotexture depth standards (Tab. 2).

Table 2. Macrotexture depth standards [11].

\begin{tabular}{|c|c|}
\hline Pavement element & $\begin{array}{c}\text { Reliable } \\
\text { macrotexture depth } \\
\text { (mm) }\end{array}$ \\
\hline Main and additional traffic lanes & $0.6-1.0$ \\
\hline $\begin{array}{c}\text { Acceleration and decceleration } \\
\text { lanes, sliproads and PPO lanes } \\
\text { (tolling points) }\end{array}$ & $0.8-1.2$ \\
\hline SPO (tolling station) lanes & $0.4-0.6$ \\
\hline
\end{tabular}

Additionally, measurement execution principles within the diagnostics of pavement surfaces are stipulated in an annex to Regulation no. 34 of the General Director of National Roads and Motorways of 30 April 2015, Diagnostics of the conditions of the surface and its elements. Application guidelines [12]. According to this document, the condition of a surface macrotexture is diagnosed with the profilometric method, based on measuring the surface profile with a mobile profilograph. Moreover, it indicates that a surface macrotexture indicator is the mean profile depth $M P D$.

Summing up, it can be concluded that contemporary texture tests (micro- and macrotexture) on road surface are conducted, based on the same methods as in the case of airfield pavements, i.e., the volumetric and profilometric methods, pursuant to the same normative documents $[2,10]$.

In practice, mobile laser profilographs and stationary laser devices, e.g. the CTM (Circular Track Meter) are most commonly used for the measurements [5].

\section{Test results}

Field tests conducted in 2017 at two domestic Air Ports. Runway airfield pavements (DS Runway no. 1 - pavement executed in the cement concrete technology and DS no. 2 - pavement executed in the asphalt concrete technology) were evaluated. The evaluated pavements were of similar age, and after an approximately two years of operation.

Pavement texture depth measurements were conducted with the use of the volumetric method, as per the PN-EN 13036-1:2010 [10]. Simultaneously, both pavements were subjected to the evaluation of roughness conditions with the use of an airport surface friction tester (ASFT) on a T-10 trailer (DS no. 1) and a manual, portable T2Go friction tester (DS no. 2), as per NO-17A501:2015 Airfield pavements. Roughness tests [13].

In the case of DS no. 1, the measurements were performed in three cross-sections $(\mathrm{km} \mathrm{0+500,1+600} \mathrm{and}$ $2+700)$. Whereas in the case of DS no. 2, the measurements were performed in five cross-sections $(\mathrm{km}$
$0+500,0+900,1+200,1+700$ and 2+200). Each crosssection included two test points, located at a distance of approx. $4 \mathrm{~m}$ from the runway axis, one on the southern side of the runway (marked $\mathrm{S}$ ), the second one - on the northern side (marked $\mathrm{N}$ ). In order not to disturb the results, the measurements were taken on pavements free from any connections or process joints. No pavement surface cracking was identified, which would prevent the measurement. Prior to each test, the surface was thoroughly cleaned and dedusted, and the measurement point covered with a wind-protector. In the area containing rubber from aircraft tyres, the measurement was performed in places with relatively no rubber.

The obtained field tests results are shown below in graphic form (Fig. 6 and Fig. 7).

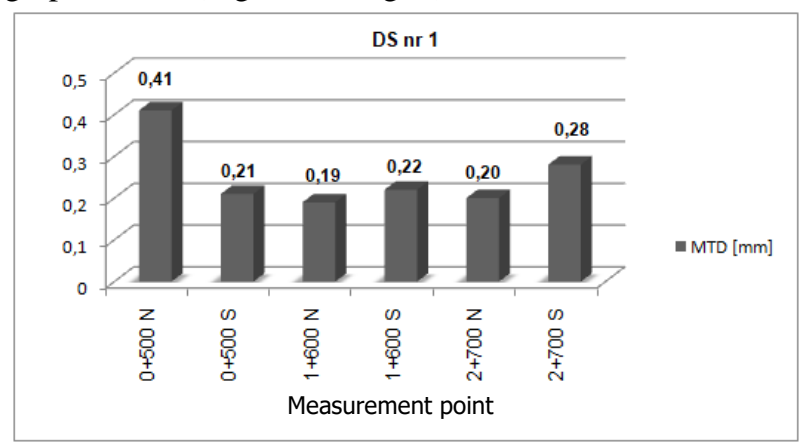

Fig. 6. Texture depth test results - DS no. 1

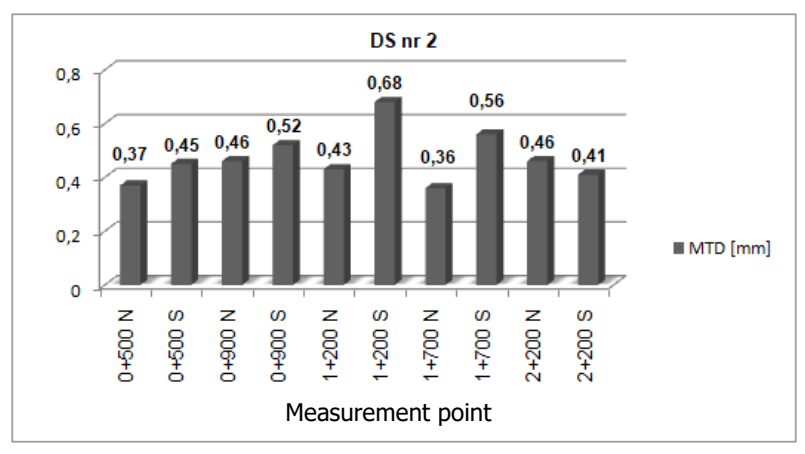

Fig. 7. Texture depth test results - DS no. 2

The following mean texture depth $M T D$ values for the evaluated runway pavements were obtained during the measurements: for DS no. 1 (pavement executed in the cement concrete technology) $\mathbf{- 0 . 2 5} \mathbf{~ m m}$, and for DS no. 2 (pavement executed in the asphalt concrete technology) $0.47 \mathrm{~mm}$.

Respectively, based on the conducted roughness measurements, the obtained mean friction coefficient values were: for DS no. 1 - $\mathbf{0 . 6 5}$, while for DS no. 2 - $\mathbf{0 . 6 0}$. The obtained values indicate that they meet the normative requirements in terms of roughness, defined for surfaces "in operation".

When analysing the texture depth test results, it can be concluded that asphalt concrete pavement exhibits a more complex texture (value almost two times bigger) than the cement concrete one. Please note that the difference between the obtained friction coefficient mean values is not that big. Nonetheless, the obtained results confirm that pavements with a texture depth below $1 \mathrm{~mm}$ 
can still exhibit good skid resistance properties, hence, can still be safely used by aircraft.

\section{The direction for the development of an airfield pavement micro and macrostructure test method}

The authors, in cooperation with a broader research team, attempted to determine the impact of texture on airfield pavement roughness, or rather the relationship between these two values.

Within the attempt, the authors already commenced field tests with one of their airfield pavement friction testers, which was adapted for simultaneous, dynamic airfield pavement texture (micro- and macrostructure) measurements (Fig. 8). The measurement is conducted via a high frequency $2 \mathrm{D} / 3 \mathrm{D}$ profile laser scanner. The field tests are conducted on cement and asphalt concrete airfield pavements, in conditions specified for measuring the friction coefficient according to applicable domestic and international regulations, i.e., at a measurement speed of $65 \mathrm{~km} / \mathrm{h}$ and $95 \mathrm{~km} / \mathrm{h}$. At the same time, for comparative and correlation purposes, spot measurements of the texture according to applicable normative regulations are performed (with the volumetric, as well as the profilometric method).

It needs to be stressed that there currently is not interconnection in aviation documents between the criteria for airfield pavement texture depth parameter and the friction coefficient parameter measurements.

Based on the accumulated population of field test results, the authors would like to determine the impact of texture on airfield pavement roughness. This, in turn, is supposed to constitute a basis for the development of acceptance criteria for newly constructed and renovated airfield pavements, relative to the criteria in terms of the friction coefficient.

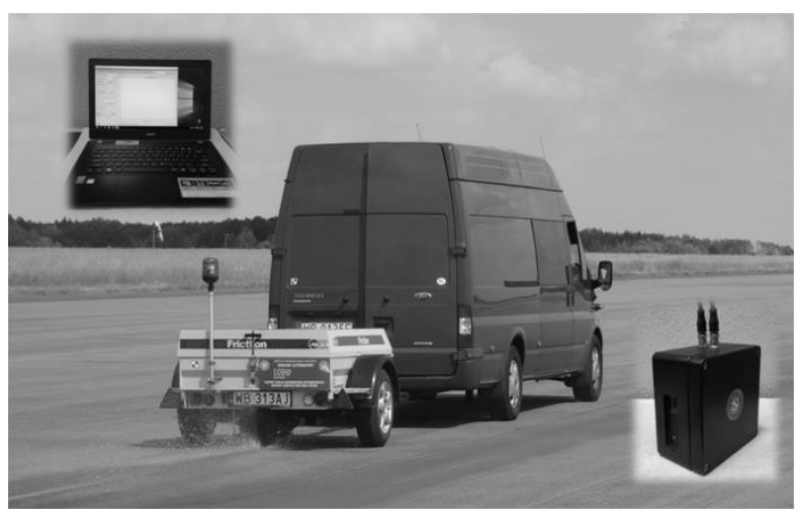

Fig. 8. Pavement texture measuring system - authors' suggestion [source: AFIT archives].

\section{Conclusions}

Airfield pavement roughness condition, as one of the elements in the process of evaluating their technical condition, has an undoubtedly significant impact on the safety of air operations executed by aircraft. A more indepth analysis of the issue of tyre/pavement contact surface friction, we come to the conclusions that it is a complex phenomenon, depending on many factors. The most important include the type of material used to construct the pavement, pavement texture, moistness, presence of contaminations or pavement defrosting agents during its winter maintenance. An important property, directly related with the friction coefficient is the airfield pavement texture depth (micro and macrotexture).

Applicable reference documents regarding the issue of airfield pavement textures raise a lot of doubt in practice. Maybe not in terms of the test method themselves, because they are rather understandable, but surely in terms of the requirements and the assessment criteria for the obtained results. The most important European document issued by EASA [4], although defining the required texture depth, only refers to the runway, furthermore, with only new pavements. So should we do with other AFE, what with already operated pavements? There is also a runway classification, based on information regarding the texture, but it raises doubts in terms of interpretation.

The skid resistance properties of the pavement (airfield and road surfaces) have been and still are the subject of research, which are carried out by research centers as well as state aviation and road institutions around the world. The effect of this are abundant documents, apart from those already mentioned in the paper, which also include the review of the measurement methods of skid resistance properties [e.g. 14, 15]. Research centers focus on conducting research in this area, often within the framework of assigned research projects [16] and presentation of the results of their work $[5,17,18]$. When reviewing the literature in the subject, the authors noticed that the current research works are primarily aimed at the possibility of forecasting the roughness of the surface (coefficient of friction) based on texture measurements (micro and macrotexture) carried out in laboratory and field conditions.

In light of the above, the authors attempted to determine the criteria for a texture depth parameter. The basic assumption was for them to be strictly linked with the airfield pavement friction coefficient parameter, i.e., for them to relate to values characterizing individual age intervals of the pavements, i.e.: "value for new pavement", "values for pavements in operation, after exceeding which, remedial actions should be taken" and „, minimum limit values”.

Developing a solution, which enables simultaneous measurement of the macrotexture and the friction coefficient of airfield pavements according to the conditions set out for measuring airfield pavement roughness (as per the applicable regulations), will undoubtedly be an innovative solution in diagnostic tests of airfield pavements.

The authors are planning to conduct further field tests, aimed at expanding the existing database, with its analysis enabling the determination of the impact of texture on airfield pavement roughness, and the development of its assessment criteria. The effects of conducted work in this field will constitute a basis for further elaborations associated with the issue of airfield pavement texture. 


\section{Literature}

1. Wytyczne nr 2 Prezesa Urzędu Lotnictwa Cywilnego z dnia 25 stycznia 2016 r. $w$ sprawie metod oceny, pomiaru oraz raportowania stanu nawierzchni drogi startowej [Guidelines no. 2 of the President of Civil Aviation Office of 25 January 2016 on the methods of evaluating, measuring reporting runway pavement condition], (2016)

2. PN-EN ISO 13473-1:2005 Charakterystyka struktury nawierzchni przy użciu profili powierzchniowych. Część 1: Określenie średniego profile głębokości [Characteristics of pavement structure with the use of surface profiles. Part 1: Determination of the mean depth profile].

3. M. Wesołowski, P. Iwanowski, Interpretacja właściwości przeciwpoślizgowych nawierzchni drogowych $i$ lotniskowych na podstawie pomiaru wspótczynnika tarcia [Interpretation of skid resistance properties of road and airfield surfaces, based on measuring the friction coefficient], Autobusy: technika, eksploatacja, systemy transportowe, 12/2017, 159 - 164, (2017)

4. Załącznik do Decyzji Dyrektora Wykonawczego EASA nr 2017/021/R z dnia 08 grudnia 2017 r. wdrażającej wydanie czwarte Specyfikacji Certyfikacyjnych (CS) oraz Materiatów Zawierajacych Wytyczne (GM) do Projektowania Lotnisk CS-ADR-DSN [Annex to the Decision of the Executive Director of EASA no. 2017/012/R of 8 December 2017, introducing the fourth edition of the Certification Specification (CS) and Guidance Materials (GM) to Aerodromes Design CS-ADRDSN], (2017)

5. M. Wasilewska, W. Gardziejczyk, P. Gierasimiuk, Ocena właściwości przeciwpoślizgowych nawierzchni betonowych $z$ odkrytym kruszywem $w$ poczatkowym okresie ich użytkowania [Assessing the skid resistance properties of concrete pavements with open-faced aggregate, in the initial operating period], Roads and Bridges - Drogi i Mosty, 16, 295 - 308, (2017)

6. Załącznik 14 ICAO do Konwencji o Międzynarodowym Lotnictwie Cywilnym, Lotniska Tom I - Projektowanie i eksploatacja lotnisk, wydanie 6 [Annex 14 ICAO to the Convention on International Civil Aviation, Airfield Volume I Engineering and operaton of airfields, issue 6], (2013)

7. Doc. 9157 ICAO AN/901 Aerodrome Design Manual Part 1 - Runways, ICAO, third edition, (2006)

8. Advisory Circular no: 150/5320-12C, U.S. Department of Transportation, Federal Aviation Administration (FAA), (1997 as am.)

9. Doc. 9137 ICAO AN/898 Airport Service Manual Part 2 - Pavement Surface Conditions, ICAO, fourth edition, (2002)

10. PN-EN 13036-1:2010 Cechy powierzchniowe nawierzchni drogowych $i$ lotniskowych. Metody badań. Część 1: [Road and airfield surface characteristics. Test methods. Part 1: Measurement of pavement surface macrotexture depth using a volumetric patch technique]

11. Rozporządzenie Ministra Infrastruktury $\mathrm{z}$ dnia 16 stycznia 2002 r. w sprawie przepisów technicznobudowlanych dotyczacych autostrad ptatnych [Regulation of the Minister of Infrastructure of 16 January 2002 on the technical-construction legislation regarding tollways], (2002)

12. Załącznik do Zarządzenia $\mathrm{Nr} 34$ Generalnego Dyrektora Dróg Krajowych i Autostrad z dnia 30.04.2015 roku, Diagnostyka stanu nawierzchni $i$ jej elementów. Wytyczne stosowania [Annex to Regulation no. 34 of the General Director of National Roads and Motorways of 30 April 2015, Diagnostics of the conditions of the surface and its elements] (2015)

13. NO-17-A501:2015 Nawierzchnie lotniskowe. Badanie szorstkości [Airfield pavements. Roughness test]

14. Runway friction characteristics measurement and aircraft braking $(\mathrm{RuFAB})$, final report volume 3 functional friction, Research Project European Aviation Safety Agency 2008/4, (2010)

15. J.W. Hall, K.L. Smith, L. Titus-Glover, J. Wambold, T. Yager and Z. Rado, Guide for Pavement Friction, NCHRP Web-only Document 108, Contractor's Final Report National Cooperative Highway Research Program Project 01- 43, Transportation Research Board of the National Academes, (2009)

16. A. Ueckermann, D. Wang, M. Oeser, B. Steinauer, Calculation of skid resistance from texture measurements, Journal of Traffic and Transportation Engineering, 2 (1), 3 - 16, (2015), This study was conducted as part of a research project funded by the German Federal Ministry of Economy and Technology No. 19S11002

17. J. Meegoda, S. Gao, Evaluation of pavement skid resistance using high speed texture measurement, Journal of Traffic and Transportation Engineering, 2, (2015)

18. A. Pożarycki, J. Fengier, M. Wyczałek, P. Skrzypczak, M. Wesołowski, K. Blacha, Analiza wyników metody fotogrametrycznej $w$ świetle właściwości przeciwpoślizgowych nawierzchni [Analysis of the results of photogrammetric method in the light of pavement skid resistance properties], Drogownictwo, 3/2017, 75 - 84, (2017), Project: "Intelligent monitoring system of technical pavement condition", conducted under the Polish grant of National Center for Research and Development No. 244286 